\title{
Drought Tolerant Rice Variety Sahbhagi dhan Option in North Chotanagpur Region of Jharkhand for Sustainability and towards Food Security: A Hope for Rain Fed Areas
}

\author{
DK Raghav ${ }^{1}$, Indrajeet ${ }^{1}$, Dharmjet Kherwar ${ }^{1}$ and Yogesh Kumar ${ }^{2}$ \\ ${ }^{1}$ Krishi Vigyan Kendra, Ramgarh, India \\ ${ }^{2}$ ICAR-Central Rainfed Upland Rice Research Station, Hazaribag, Jharkand, India
}

*Corresponding Author: DK Raghav, Krishi Vigyan Kendra, Ramgarh, India.

Received: June 17, 2019; Published: July 03, 2019

DOI: $10.31080 /$ ASAG.2019.03.0554

Rice (Oryza sativa L.) is the staple food of more than three billion people in the world, most of whom live in Asia. Rice is cultivated under diverse ecologies ranging from irrigated to rainfed upland to rainfed lowland to deep water. The rainfed ecosystem represents about $38 \%$ of total rice area, accounting for $21 \%$ of world rice production. Eastern states of India accounting for $27.26 \mathrm{~m}$ ha rice area, out of which nearly $4.28 \mathrm{~m}$ ha area is prone to frequent drought. The frequent occurrence of drought has been identified as the key to the low productivity of rice in rainfed ecosystems, particularly in eastern region of India. The eastern region comprises of Bihar, Eastern Uttar Pradesh, Odisha, West Bengal Jharkhand, Chhattisgarh and plains of Assam, represents 21.85\% geographical area of the country and supports to $33.64 \%$ of country food production. Though the region is endowed with rich natural resources but the production level is remained low. In eastern India, rice production is directly correlated with regional and national food security. Rice productivity in these drought prone areas is poor and unstable; emphasis is shifting towards drought prone rainfed rice areas which offer a great potential in enhancing rice production and productivity. Most of the current high-yielding varieties of rice grown in rainfed areas are bred for irrigated ecosystems and they are highly susceptible to water scarcity condition. Keeping this fact in view, there is urgent need to disseminate and adoption of high yielding drought tolerant varieties to achieve food self sufficiency at national level from eastern region.

Hazaribag district belong to the plateau region of Chota Nagpur is characterized by humid and sub humid tropical monsoon. Exploitation and encroachment in many areas with a life style geared to forest ecology pockets with chromic drought conditions, erratic rainfall low ground water level, insufficient agricultural dairy and fishery activities area the cause of poverty. The average annual rainfall in the State is about $1200-1400 \mathrm{~mm}$, of which $82 \%$ is received during the period of June to September, and rest $18 \%$ in the remaining months. Despite the fact that the state has a good rainfall, the surface water availability to agriculture is not sufficient due to inadequate storage facilities. The net irrigated area of state is $12 \%$, which is substantially lower than the all-India level (40\%). Being largely rainfed area, the state has a cropping intensity of $116 \%$. The land surface being uneven is subject to erosion, causing loss of soil and plant nutrients. Foods security situation in the newly formed state is very serious. Due to mono-cropping habit of the state unfortunately, suffers from serve nutrition's and food deficiency. Rice which is the preferred stable diet of the people is currently available at about $160 \mathrm{gm} /$ day which is $35 \%$ of the per capital requirement for cereals. The requirement is expected to increase up to $225 \mathrm{gm} /$ day. Now over coming to this problem farmers are attracting for hybrid variety which is easily available in market and Seed Company attracting companies for adopting the hybrid seed. Initially the average production of local varieties 11.52 /ha and hybrid are playing major role for improving the production and productivity. Instead of that there no such guideline for monitory the hybrid seed adoption which should not cross more the $50 \%$ in Rice cultivation of reached up to $68 \%$. Now this state becomes the hub of hybrid seed dump yard because the awareness for HYV is not circulation properly. In recent year dough is the main reuse for adopting the hybrid for sufficient food production. Due to unbalance dose of fertilizer and without proper research trial for disease and pest resistance is creating the problem which is becoming serious threat and farmer were facing low yield syndrome instead of using hybrids.

Despite the importance of drought as a constraint, little effort has been devoted to developing drought-tolerant rice cultivars. Most of the high-yielding varieties-IR 36, IR 64, Swarna, and Sambha Mahsuri grown in rainfed areas are varieties bred for irrigated ecosystems and they were never selected for drought tolerance. In drought years, these varieties inflict high yield losses, leading to a sudden decline in the country's rice production. Because of the absence of high-yielding, good-quality drought-tolerant varieties, farmers in the rainfed ecosystem continue to grow these varieties. Farmers of drought-prone areas require varieties that provide them with high yield in years of good rainfall and sustainable good yield in years with drought. In rainfed areas, upon failure 
of rain or a long spell between two rains, drought stress can occur at the seedling, vegetative, and reproductive stage of the rice crop or it can be intermittent drought depending upon the rainfall pattern and distribution. Among all these, drought at the reproductive stage has been identified as the most detrimental to grain yield. Moreover, in most rainfed regions, the probability of occurrence of terminal reproductive-stage drought is high due to the early withdrawal of monsoon rains. By employing direct selection for grain yield under drought, several promising breeding lines for rainfed lowlands and uplands have been identified recently. Similarly, some drought tolerant varieties (Sahbhagidhan, SuskSamrat, CR dhan, Anjali, Vandana and Indira Baranidhan) released by different institutions for eastern India.

The rainfall pattern is also revealing the alarming situation in the region because duration of Rainy day's and Intensity of rain is creating drought, because heavy rain splash may not be stored in soil and in this situation farmers were not preferring long duration variety. The stress tolerance, Short duration and high yielding variety Sahbhagidhan creating hope for farmers and way of food security and eco-sustainability and social security also. We conducted 100 ha demonstration in Hazaribag district mostly drought prone area were preferred and training given to selected area farmer groups regarding cultivation package and comparative benefits were also discuss on the bases of micro situation of forming. We provide all the technical help by training follow up farmer meeting and discussion for the popularizing this variety Sahbhagidhan. During the cropping period select Five farmer from different drought prone Blocks \& village and 5 farmer from another area for comparing the impact after harvesting we discuss with all of them selection farmers. A different aspect and we found much unexpected feedback from the farmers which is discussing as point given below.

Rice variety Sahbhagidhan was developed by Central Rainfed Upland Rice Research Station Hazaribag in collaboration with International Rice research Institute, Philippines. It has been released and notified in 2009 and 2010, respectively. It is highly drought tolerant variety and recommended for cultivation in rainfed upland and lowland areas of eastern states, particularly in Jharkhand, Bihar, UP and Odisha. Sahbhagidhan is maturing in 105-110 days in plain areas and 110-115 days in upland. Transplanting of this variety should be done between mid-Junes to first week of July. Seed of sahbhagidhan is long and bold and having intermediate amylose content.Sahbhagidhan is highly resistant to leaf blast and moderately resistant to brown spot and sheath blight. Productivity of sahbhagidhan is 2.0-2.5 t/ha under drought stress and 3.8-4.5 t/ ha without stress.
- Drought tolerance: Since 2009 in Hazaribag district, the selective areas for demonstration were suffering with severely drought where farmers were unable to take paddy crop during drought and erratic rainfall situation in this area. But the variety Sahbhagidhanhas immense moisture stress tolerance capacity up to 10-15 day which provide the shield for crop and farmer's harvest 35.0 to $62.0 \mathrm{q} /$ hagrain yield. The farmer's were advised for both method of cultivation like direct seeded and transplanting method which provide more option for cultivating the Paddy compare to hybrid in the selected field were fellow since last 5 year due to drought in this area like Barhi and Chouparan.

- Increase yield: The yield harvested from $35.0 \mathrm{q} /$ ha from DSR and $62.0 \mathrm{q} /$ ha transplanted field, but an average yield was 28.0 q/ha by DSR Method and 53.0 q/ha from transplanting method which was $40 \%$ maximum from another variety like from in drought prone axis.

- Risk aversion: Due the drought resistance performance of Sahbhagidhan, the farmer assured about yield and employment in the field, because they assured to growth crop that he will harvest definitely respectable yield from the field.

- Water Saving: During the Kharif season is district some block like Barhi, Chouparan, Barkattha and Chalkusha were well know popular for insufficient rain spell, rainfall and scarcity. But Sahbhagidhan performed well during the cracking of soil in field and the required light rain may help the crop to growth because heavy rain spell was 10-15 day intervals and other hybrids required flood water irrigation situation in the field in 7-8 days intervals. The short duration of variety was helpful to decrease the water requirement of crop. Which other hybrid took more the 125-130 day up to harvesting and required frequent rain. Requirement of water during critical stage was also less compare to hybrids.

- Pest and Disease Management: Due to short duration if the crop will be transplanted/sown timely the pest and disease approver will be negligible if during the accelerated growth of crop the Pest invasion will be occur the damage will be below economic through held level. In Jharkhand the farmers transplanted 25 to 35 day old seedling and up to 15 thAugust. The late transplanting seedlings are preferable food of stern borer, Case warm and gall midge. Because mid August to mid September heavy rain spell received and water lodging may occurred in law land and mid land also which provide congeal temperature and environmental for damage and the Paddy crop in not is middle Stage in tillering stage may provide better succulent food for pest and stagnant wa- 
ter provide source of transplanting for borer, Leaf folder, gall midge and case warn. If the damage will be negligible the cast of Plant Protection Chemicals will be disease and cast of Production will also be decrease.

- Avoidance Preference: The variety may be transplanted early help to avoid the rodent damage because the fast growth and short duration if time is not enough for providing the favorable condition for rodent population. During the harvesting a survey uses conducted an Rodent damage avoidance farmer observe that rodent did not prefer Sahbhagidhan field for burrowing the move towards hybrid fields. The rodents are causing 12 to $35 \%$ loss in Hazaribag district depends on rainfall pattern. So selection of this variety is compatible for avoiding the rodent loss in field.

- Increase cropping intensity: Jharkhand is known for manner cropping, one reason is anticipating that harvesting time and crop duration may delay the possibility of second crop like Chick Pea, Lentil Mustard, Linseed, Pea, low water requirement crop. Although thus crop can utilize the residual moisture, Long duration variety and transplanting and the availability of sufficient rain may shift the harvesting time. But this drought resistance variety may be sown during the low moisture by the DSR method may provide the opportunity to farmers and increase the cropping intensity also which is $110 \%$ may gown up to $160 \%$.

- Momentary gain/additional Income: Judiciously/minimum requirement of Plant Protection chemical by the crop may reduce the cast of cultivation. And during the cropping season the availability of credit is very limited to farmers and it may help to manage the fund and reduce the possibility of tending possibility for farmer. Increase the cropping intensity may provide another crop and farmer can produce more crop which will provide additional income for farmer from family. Which is directly help to farmer's for improving her family life and short out the credit problem.

- Eco friendly: Due to low incidence of disease and Pest the application of Agro chemical is limited which reduce the burden of harmful chemical an soil and flora. It also increases the habitat of Natural enemy which mark more effort for contributing the pest and rodents. Vertebrate like Snakes, Owl, and Frog may increase his population which helps to mitigate the harmful population of rodent, bores and other pest and also create eco friendly environment to maintain the grain ecology. It also avoids the risk of poisons incidence in farmer family because during the stress involvement the respective member could be choose the harmful \& dangerous option for suicide.
- Farm Investment: The adoption of advanced Agronomical practice for growing Sahbhagidhan may increase the yield with surely economic production which may provide to create more facility and investment. Because during drought situation the drought prone area farmer's always depend and rain, so they avoid to investment on like Agriculture machinery and in puts, which directly affected Paddy crop production and Possibility for increasing cropping system. It also help to stylize the Kisan credit card by farmer and assured return may help to return the credit many timely to Bank do that banking sector may also help to push the agriculture growth by brooding more fund in agriculture economy.

- Direct Seeding: The rainfall patter in erratic Hazaribag district mostly $50 \%$ of the cultivated are were suffered by drought problem. In this situation many time farmers escape the transplanting instead of nursery raising because at the transplanting time the drought spell miss the opportunity of transplanting. Sometime late transplanting were done by the farmers in this situation crop suffer by many disease and pest in younger stage and unable to recover the less done by insect. But at the receiving first shower the farmer may start tillage operation in the field and sowing the Paddy seed by direct seeded method. This method received only soil moisture and no standing water in field which in early available during the sowing time. Farmers can also sowing timely so that can harvest timely and use the residual moisture for Rabi season crop.

- $\quad$ Reduce the open grazing intensity: It provide the more fodder for animal because mono-cropping harvested straw is not sufficient o provide the fodder round the year and help to prevent the open grazing which also create more option for utilize and introduce more diversification in Agriculture . In result more milk may produce and availability of protein will be in crease for farmer family and excess milk \&meat may create opportunity of employment. The report of ILRI also reveals that the straw of Sehbhagi was also preferred by animals due to more mineral availability in straw. The height of crop is also good which provide the Paddy straw compare to other popular variety. Because adoption of any variety, the production of Paddy straw is also meaning full approaches.

- Grain quality: The size of grain and cocking also a parameter for adopting by farmers, because rice is the more step food by different community in different items like fermented Juice of Rice, chuda, paraboiled rice. The farmer reported that the taste of the rice is sweetened and during cocking the flower is appetite.

- $\quad$ Market: It is purchasing by miller for making Chuda which is good sign for popularizing this variety. During milling the 
grain quality found better compare to other hybrid and in market easy to sole the variety for any variety easily purchase by grain purchase agent helpful for adopting by farmer community.

- Migration: Easily growing in soil moisture available in soil during rainy season give timely engagement for farmers and increase the cropping intensity may create the more Man days, because after harvesting mostly $25-30 \%$ farmer family member migrated from her native place it create more health problems and regular income availability by agriculture may induce the pressure against agriculture. It seems that due to this impact rural youth does not prefer the agriculture. So it is becoming serious national problem with available technologies are capable to generate more employment opportunity for rural youth and farm labor also. It creates interest towards farming and helps the nation to reduce the import pressure on Indian economy and save the currency. So the currency may be utilized in infrastructure development in agriculture sector which provide sustainability and food security also. The availability of employment round the year may solve the extremist mentality interference in our social structure which is also a big threat for society may change the mindset and reduce the migration.

\section{Summary}

The challenge of growing water scarcity and frequent occurrence of drought has been identified as the key to low rice productivity in rainfed ecosystems of eastern region, threatening food security. Because of absence of high yielding, good quality drought tolerant varieties, farmers in rainfed ecosystem continue to grow traditional varieties, leads to high yield losses. Adoption of high yielding drought tolerant rice varieties Sahbhagi dhan, Shusk samrat, CR dhan 40, Vandana, Anjali, Naveen and Indira Baranidhan will play pro-active and decisive role in developing sustainable food production and lead for food security among farm families in the stress (water scarcity) prone areas of eastern region of India.

\section{Volume 3 Issue 8 August 2019}

(C) All rights are reserved by DK Raghav., et al. 